\title{
Ecogeographical distribution of wild, weedy and cultivated Sorghum bicolor (L.) Moench in Kenya: implications for conservation and crop-to-wild gene flow
}

\author{
Evans Mutegi $\cdot$ Fabrice Sagnard $\cdot$ Moses Muraya $\cdot$ Ben Kanyenji · \\ Bernard Rono - Caroline Mwongera • Charles Marangu · Joseph Kamau • \\ Heiko Parzies · Santie de Villiers · Kassa Semagn · Pierre Sibiry Traoré • \\ Maryke Labuschagne
}

Received: 22 December 2008/ Accepted: 6 July 2009/Published online: 31 July 2009

(C) Springer Science+Business Media B.V. 2009

\begin{abstract}
The potential gene flow between a crop and its wild relatives is largely determined by the overlaps in their ecological and geographical distributions. Ecogeographical databases are therefore indispensable tools for the sustainable management of genetic resources. In order to expand our knowledge of Sorghum bicolor distribution in Kenya, we conducted in situ collections of wild, weedy and cultivated sorghum. Qualitative and quantitative morphological traits were measured for each sampled wild sorghum plant. Farmers' knowledge relating to the management of sorghum varieties and autecology of wild sorghum was also obtained. Cluster analysis
\end{abstract}

E. Mutegi · F. Sagnard · C. Mwongera ·

S. de Villiers · K. Semagn

International Crops Research Institute for the Semi-Arid

Tropics (ICRISAT-Nairobi), PO Box 39063-00623,

Nairobi, Kenya

E. Mutegi $(\bowtie) \cdot$ J. Kamau

Kenya Agricultural Research Institute (KARI) National

Genebank, P.O. Box 30148, Nairobi, Kenya

e-mail: e_mutegi@yahoo.com

F. Sagnard

CIRAD, UMR Développement et Amélioration des

Plantes, c/o ILRI, PO Box 30709, Nairobi, Kenya

Present Address:

K. Semagn

CIMMYT, Nairobi, Kenya supports the existence of several wild sorghum morphotypes that might correspond to at least three of the five ecotypes recognized in Africa. Intermediate forms between wild and cultivated sorghum belonging to the S. bicolor ssp. drummondii are frequently found in predominantly sorghum growing areas. Crop-wild gene flow in sorghum is likely to occur in many agroecosystems of Kenya.

Keywords Agroecosystems - Environmental risk assessment · Genetic resources · Germplasm conservation · GIS · Introgression · Morphological diversity $\cdot$ Sorghum bicolor

M. Muraya $\cdot$ H. Parzies

Seed Science and Population Genetics, Institute of Plant

Breeding, University of Hohenheim, Fruwirthstrasse 21, 70599 Stuttgart, Germany

B. Kanyenji · B. Rono - C. Marangu

KARI-Embu, PO Box 27, Embu, Kenya

P. S. Traoré

ICRISAT-Mali, BP320 Station de Samanko, Bamako, Mali

M. Labuschagne

University of the Free State, Planteteelt IB 63,

Bloemfontein, Republic of South Africa 


\section{Introduction}

Sorghum (Sorghum bicolor (L.) Moench) is believed to have been first domesticated in the north eastern quadrant of Africa, in regions that correspond to the current Southern Sudan and Ethiopia (De Wet 1978; Doggett 1988). Kenya therefore constitutes the southern fringe of this presumed domestication center. Domesticated sorghum and its wild relatives demonstrate tremendous morphological variability, which has presented challenges to taxonomists and biosystematists. The first detailed taxonomic study of cultivated sorghum and its progenitors was presented by Snowden $(1936,1955)$. He recognized 28 cultivated, 17 wild and 7 weedy "species". However, due to lack of genetic barriers between these taxa, it is now generally agreed that these are best regarded as cultivars and/or ecotypes of the S. bicolor species complex (De Wet et al. 1970; Harlan and De Wet 1972; De Wet 1978; Doggett 1988). The species complex is therefore divided into three subspecies: (1) S. bicolor ssp. bicolor encompasses all cultivated sorghum grouped into five major ecotypes (Harlan and De Wet 1972), (2) S. bicolor ssp. verticilliflorum (Steud.) De Wet comprises all the closest wild relatives of cultivated sorghum and (3) S. bicolor ssp. drummondii (Steud.) De Wet which is a heterogeneous weedy sorghum group derived from hybridization between S. bicolor ssp. bicolor and S. bicolor ssp. verticilliflorum. Wild sorghum are grouped into four basic botanical varieties (De Wet et al. 1970; De Wet 1978; Doggett 1988), corresponding to four of the Snowden's "species" (Snowden 1955), namely S. arundinaceum (Desv.) Stapf, S. verticilliflorum (Steud.) Stapf, S. virgatum (Hack.) Stapf and S. aethiopicum (Hackel) Rupr. ex Stapf. S. arundinaceum comprise of robust and tall forest grasses in humid and sub-humid West Africa. It has large leaves and a broad loose panicle with pendulous branches. S. verticilliflorum is the most widespread wild sorghum in sub-Saharan Africa. It is abundant in dry savannas and differs mainly from $S$. arundinace$u m$ in that its panicles have non-pendulous branches. S. aethiopicum is found in the southern margin of the Sahara desert. They are shorter than $S$. arundinaceum and $S$. verticilliflorum and are characterized by smaller panicles with erect or sub-erect branches. Finally, S. virgatum is a slender desert grass occurring from Central Sudan to Egypt along stream banks and irrigation ditches.

Wild and cultivated sorghum are interfertile and grow sympatrically in many agroecosystems of subSaharan Africa. Molecular evidence of genetic introgression between wild and cultivated sorghum has been documented for the Sorghum bicolor-Sorghum halepense L.-Johnsongrass complex in the United States (Arriola and Ellstrand 1997; Morrell et al. 2005) and within the Sorghum bicolor species (Aldrich and Doebley 1992). Doggett and Majisu (1968) collected cultivated, wild and weedy sorghum in Kenya and found morphological evidence of hybridization in farmers' fields. However, neither the variability of genetic introgression in different agro-ecological zones nor the direction of gene flow between particular cultivated varieties and ecotypes of wild sorghum has been investigated at a country scale.

Sorghum is an important cereal crop in subSaharan Africa, particularly in semi-arid areas. It can provide food, malt, feed, fiber and biofuel across a range of environments and production systems. It is susceptible to a large range of pests, diseases and hemi-parasitic weeds, some of which have been shown to be difficult to control using conventional breeding and agronomic methods. Sorghum has, therefore, been proposed as a candidate crop for genetic transformation and protocols for sorghum genetic engineering have recently been optimized and successfully applied for various traits (Casas et al. 1997; Girijashankar et al. 2005; Zhu et al. 1998; Zhao et al. 2000; Gao et al. 2005; Howe et al. 2006; Ayoo 2008). In addition, transgenic biofortified sorghum are being developed for sub-Saharan Africa (Zhao 2008).

The potential of wild sorghum to provide new sources of resistance and adaptation in breeding programs have been established (Sharma and Franzmann 2001; Gurney et al. 2002; Kamala et al. 2002; Rao Kameswara et al. 2003) but only partially explored. Conversely, crop-to-wild gene flow could result in the spread of genes from both domesticated and transgenic varieties into wild populations, and possible subsequent creation of aggressive weeds or invasive plants (Ellstrand et al. 1999; Conner et al. 2003), depending on the characteristics of the introgressed genes. It can also alter wild sorghum gene 
pools through gradual genetic swamping (Ellstrand 2003) and in extreme cases cause the extinction of wild populations. These concerns have stimulated gene flow related environmental risk assessment surveys and in situ conservation programs of wild relatives of sorghum in sub-Saharan Africa, such as that reported by Tesso et al. (2008).

An overlapping geographic distribution of a crop and its wild relatives is the first pre-requisite for cropto-wild gene flow to occur. However, despite its crucial importance for biosafety and conservation decision makers, ecogeographical information for sorghum is missing or incomplete in many regions of the world (Armstrong et al. 2005), especially in subSaharan Africa. In a recent survey in Ethiopia and Niger, Tesso et al. (2008) observed an overlap in occurrence and flowering phenology between cultivated and wild sorghum, an indication of the potential for gene flow between the two congeners. Their work however, did not cover wild populations occurring outside the proximity of cultivated sorghum, nor characterized the taxonomic and/or morphological diversity of wild sorghum.

We conducted collections of wild, weedy and cultivated sorghum in the main sorghum growing areas in Kenya with a special effort to cover regions poorly prospected previously to (1) determine the main features of sorghum cropping systems, (2) extend knowledge of the geographical and taxonomic distribution of wild and weedy sorghum, (3) identify strategies to strengthen conservation programs of both cultivated sorghum and its wild relatives, and (4) estimate the potential for crop-towild gene flow to occur in different agroecosystems in Kenya.

\section{Materials and methods}

Collection of wild, weedy and cultivated sorghum

A preliminary synthesis of the distribution of cultivated and wild sorghum was compiled from accessions and herbarium specimen information available at the National Gene Bank of Kenya and the East African Herbarium. The main sorghum cultivation regions in Kenya were identified, some that have previously been covered intensely by prospectors, such as Nyanza and Western provinces and others like Turkana and Coast province with very little available information, despite indications of important wild and cultivated sorghum diversity. Our sampling strategy was therefore designed to: (1) collect a sufficient number of wild, weedy and cultivated sorghum in the four main sorghum growing areas in Kenya, (2) make special collection efforts for wild and weedy sorghum in general, and (3) fill the geographical gaps in germplasm conservation at the country scale.

The necessity to collect wild and weedy sorghum seeds before they shatter simultaneously with domesticated sorghum varieties at maturity considerably narrowed the temporal collection window for each site. In addition, sharp climatic variations often prevailed over short distances in the same region due to small-scale altitudinal variations in several mountainous parts of Kenya and some regions had two cropping seasons. We thus organized three collection trips: June-July 2006 for Turkana, Western-Nyanza and Coast provinces; February 2007 for Eastern province and July 2007 for Coastal province (second season). The Rift Valley Highlands and North-Eastern province, where limited sorghum cultivation occurred, were omitted.

During the collection, farmers were interviewed about the varieties they cultivated (seed origin, ancientness, uses and some features of the sorghum cropping systems) and their knowledge of wild and weedy sorghum distribution, ecology and dynamics were recorded.

Geographical Information System (GIS) mapping and climatic databases

Geographical coordinates and elevation data were collected for each sample of cultivated, wild or weedy sorghum using a handheld Geographical positioning system (GPS). Coordinate information of each collected sample and a digital base map of the annual rainfall distribution (National Water Master Plan, Kenya) were imported into Arc View GIS 3.2 (Environmental Systems Research Institute 1999) and used to generate patterns of association of cultivated and wild/weedy sorghum with rainfall patterns in Kenya. 
Description of wild and weedy sorghum habitats

The habitats of wild and weedy sorghum were classified into six types. Four were associated with agriculture: sorghum fields, other cereal fields, other cultivated fields and fallows. Roadsides and path edges constituted semi-natural habitats close to communication ways. Finally, permanent and temporary stream banks, inundated trenches and temporary pond shores were clustered into a single habitat and named "riverine". In cases where wild and weedy sorghum plants were found at the interface between two habitats (e.g. field margin and roadside), a half score was assigned for each habitat to calculate the overall habitat distribution scores.

Multivariate analyses of wild and weedy sorghum morphological data

Seven quantitative traits (plant height, stem length, flag leaf length, flag leaf width, panicle length, number of tillers and number of nodes) often used in the taxonomic classification of wild and weedy sorghum, were measured. Qualitative characters related to the panicle shape, the glume cover and the presence of an awn were also scored and used for botanical identifications but not included in the subsequent multivariate analyses since their distribution is not normal. The quantitative variables were normalized and served as the input table for a hierarchical classification based on Ward's algorithm (Ward 1963) on the Euclidian distance matrix among the 112 collected wild and weedy sorghum. A Mantel test was performed to assess the correlation between the geographic and morphological distance matrices (Mantel 1967) and the statistical significance of the estimated correlation was estimated using 999 permutations. To test whether geographic (regions), climatic and elevation factors could significantly explain the observed structures of wild and weedy sorghum morphological diversity, we performed a Monte Carlo test on the linear discriminant analyses based on five non-redundant quantitative variables (the number of nodes and the panicle width were discarded) using 999 permutations. The ADE4 statistical package (Chessel et al. 2004) running on the programming environment $\mathrm{R}$ ( $\mathrm{R}$ Development Core Team 2005) was used for all multivariate analyses.

\section{Results and discussion}

Main features of sorghum cropping systems in Kenya

Table 1 summarizes information on the number and origin of varieties cultivated by farmers and the utilization of modern varieties. Sorghum is cultivated within large altitudinal $(0-1,650 \mathrm{~m})$ and climatic gradients (300-1,800 mm/year). In Western and Nyanza provinces, it is very important in cropping systems and farmers rely on a large varietal diversity, mainly to meet subsistence needs. In the Eastern province, the distribution of cultivated sorghum diversity is more uneven, varying from 1,000 to $1,500 \mathrm{~m}$ above sea level (asl) on the eastern slope of Mt Kenya down to more moderate altitudes (500$1,000 \mathrm{~m}$ asl) in the lower regions occupied by the Kamba community. Farmers in the Lake Turkana region grow the most diverse pool of sorghum in Kenya and also have the most diverse uses of the crop for food, beverage, animal feed and construction. Sorghum cultivation is marginal in the coastal region. In the mainland of coast province, few farmers grow local varieties. Introductions of modern varieties on newly established farms are common and farmers in such areas frequently expressed the need to access a larger diversity. The situation is different on the Lamu islands (and probably also on Funzi island, according to the interviewed neighboring mainland farmers) of the same province where sorghum landraces are still abundantly cultivated. Interestingly, it seems that geographical isolation has contributed to the preservation of traditional agricultural systems among the Swahili communities of Lamu.

Turkana farmers grow only landraces. Dissemination of modern varieties is moderate in the Eastern and Coastal provinces and low in the Western and Nyanza provinces (Table 1). However, the predominant contribution of only two varieties (Serena and Seredo) to the introduced improved germplasm, might be responsible for narrowing the genetic basis of sorghum in Kenya in the long term. These two varieties have large adaptive spectra and are often distributed by emergency seed programs after a drought, regardless of environmental constraints to their production. Furthermore, these two varieties are among the few for which seeds are produced commercially by a private company in Kenya and 
Table 1 Importance of sorghum in cropping systems: varietal abundance, proportion of landraces and origins of seed in the four main sorghum growing areas of Kenya

\begin{tabular}{|c|c|c|c|c|c|}
\hline \multirow[t]{2}{*}{ Region } & \multicolumn{2}{|c|}{ Number of varieties per site ${ }^{\mathrm{a}}$} & \multirow{2}{*}{$\begin{array}{l}\text { Percentage of } \\
\text { landraces }\end{array}$} & \multicolumn{2}{|l|}{ Origin of seed by percentages } \\
\hline & Range $^{b}$ & Average $^{c}$ & & & \\
\hline Turkana & $5-18$ & $10.5(6.557)$ & 100 & Not available & \\
\hline Coast & $1-5$ & $1.4(1.003)$ & 58 & $\begin{array}{l}\text { Relative in same village } \\
\text { Market } \\
\text { Friend in same village } \\
\text { Relative in another village } \\
\text { Government } \\
\text { Friend in another village } \\
\text { NGO }\end{array}$ & $\begin{array}{r}44.8 \\
20.7 \\
10.3 \\
6.9 \\
6.9 \\
6.9 \\
3.4\end{array}$ \\
\hline Nyanza/Western & $1-10$ & $2.5(2.195)$ & 70 & $\begin{array}{l}\text { Relative in same village } \\
\text { Market } \\
\text { Relative in another village } \\
\text { Friend in same village } \\
\text { Friend in another country } \\
\text { Government } \\
\text { Relative in another country }\end{array}$ & $\begin{array}{r}55.0 \\
21.7 \\
10.0 \\
6.7 \\
3.3 \\
1.7 \\
1.7\end{array}$ \\
\hline Eastern/Central & $1-9$ & $2.4(1.782)$ & 51 & $\begin{array}{l}\text { Market } \\
\text { Relative in same village } \\
\text { Relative in another village } \\
\text { Government } \\
\text { Friend in same village } \\
\text { Friend in another village } \\
\text { NGO }\end{array}$ & $\begin{array}{r}30.4 \\
21.7 \\
19.6 \\
17.4 \\
4.3 \\
4.3 \\
2.2\end{array}$ \\
\hline
\end{tabular}

a The collection sites represent a group of neighboring households. Distribution of farms is generally very scattered in Kenya and the crop varietal richness could not be estimated within a precise administrative or spatial unit

b Minimum-maximum

c SD in parentheses

are therefore available in large quantities. Seed systems are mainly traditional where farmers' relatives make important contributions to seed acquisitions but local markets also constitute an important source, especially in the drylands of Kenya.

Wild and weedy sorghum distribution and habitats

Wild and weedy sorghum are found in all sorghum growing areas of Kenya (Fig. 1) over a large range of agroclimatic conditions (Fig. 2). Their observed altitudinal distribution varies from sea level to $1,750 \mathrm{~m}$ asl in Nairobi. Sometimes they serve as a fodder crop or as an indicator of soil fertility. Interestingly, farmers in Turkana consume advanced hybrids for grain, but they do not replant them. Wild sorghum are well known by pastoralists like Maasai who use the stems to build animal shelters, traditional music instruments and even seats on which young boys sit during circumcision ceremonies. Different types of habitats have been identified for wild and weedy sorghum (Fig. 3). They are abundant in sorghum and other cereal fields as well as in fallows, but can also grow in disturbed habitats such as roadsides. Interestingly, several wild sorghums have also been collected far away from agricultural lands in natural riverine habitats in the drylands. A Maasai women's group close to the Tanzanian border has provided a sound description of sorghum ecological requirements: "wild sorghum grow wherever they find a sufficient amount of moisture". Notably, a Kenyan commercial seed company is selling a variety of wild sorghum under the name of "Columbus grass" as a fodder crop and whole fields of this variety were encountered on the Mwea plain in central Kenya and North of Malindi town on the Coast.

Wild and weedy sorghum morphological diversity and taxonomy

Three sorghum species occur in Kenya. In addition to Sorghum bicolor, Sorghum purpureo-sericeum 
Fig. 1 Locations of collected wild/weedy sorghum on the climatic map of Kenya
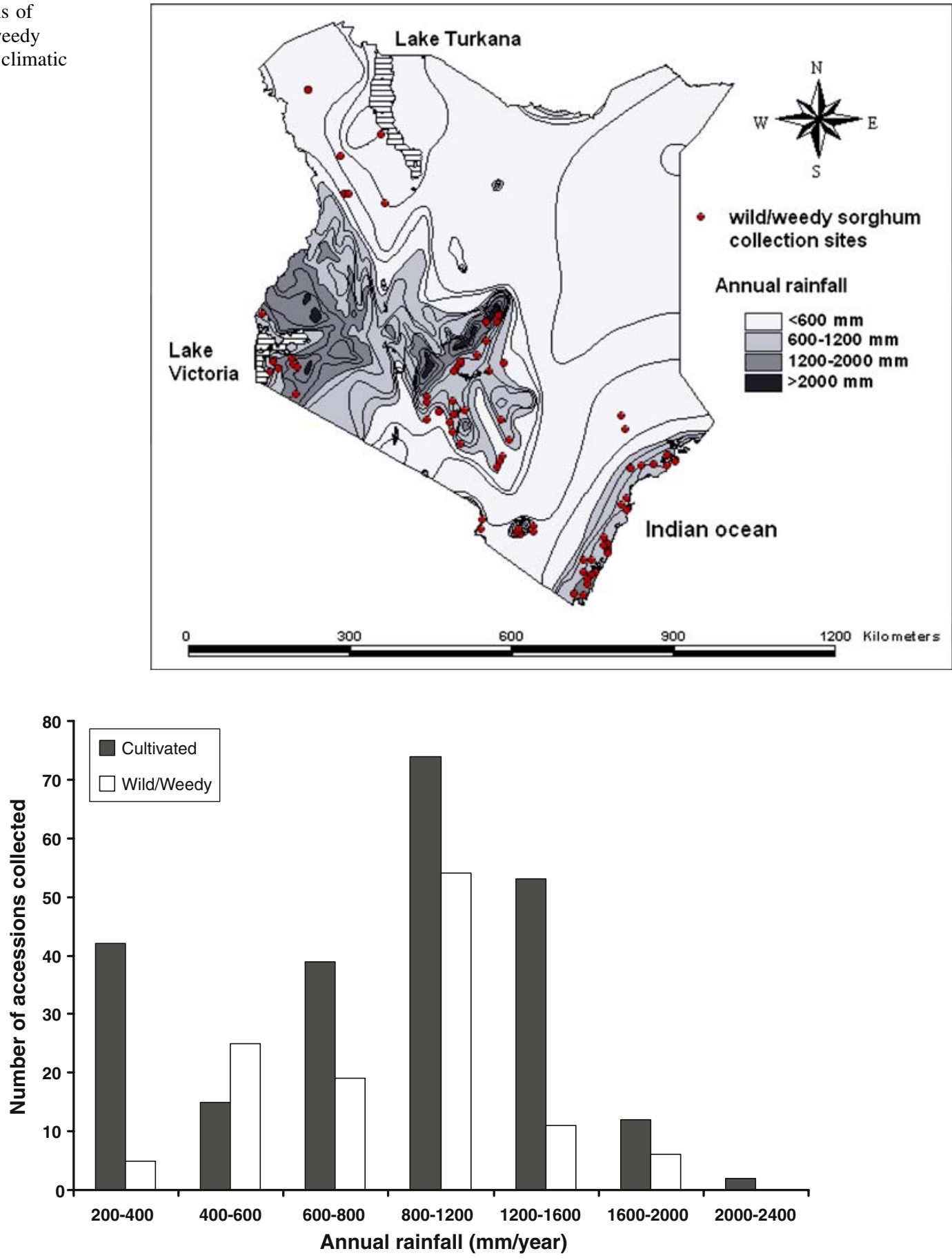

Fig. 2 Number of cultivated varieties, wild and weedy sorghum accessions collected in different climatic zones

(Hoechst. ex A. Rich.) Asch. et Schweinf. and Sorghum versicolor Andersson belong to the section Para-Sorghum (Clayton and Renvoize 1982). They are part of the tertiary sorghum gene pool and cannot cross naturally with cultivated sorghum (Harlan and De wet 1971). These have not been collected.

Extensive variability is found within wild and weedy sorghum for all morphological traits (Fig. 4). 


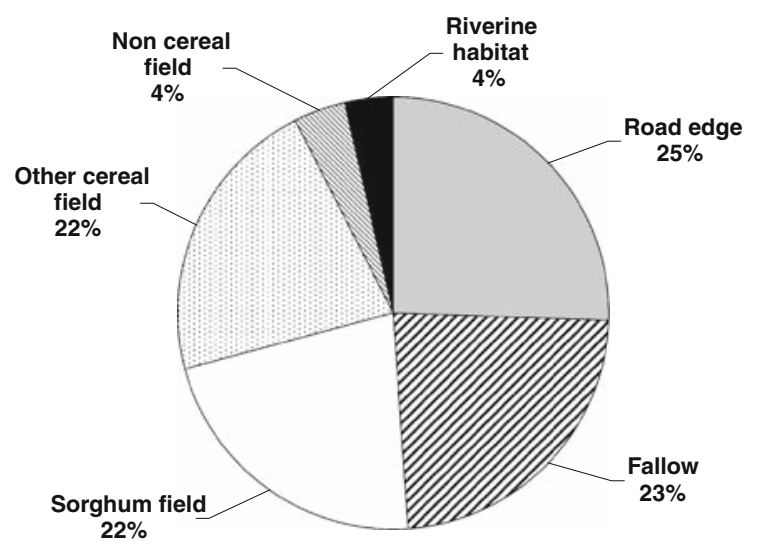

Fig. 3 Distribution of wild and weedy sorghum habitats, expressed in percentages of the total number of accessions collected in each habitat

The cluster analysis (Fig. 5) establishes a first level division between wild and weedy sorghum according to traits of vigor (height, flag leaf size, panicle size). The small wild and weedy plants further divide into two groups based on the size of the flag leaf. Group B is composed of short plants with short, narrow leaves and narrow panicles with sub-erect branches. Botanical keys (De Wet et al. 1970; Clayton and Renvoize 1982) classify them into S. aethiopicum. Among the tall wild and weedy sorghum, group C clusters sorghum that are between 2.5 and $4 \mathrm{~m}$ tall, with large leaves and broad panicles. This group is heterogeneous for panicle compactness and awn presence. Some plants collected in the Coast province far from cultivated sorghum should be classified into S. arundinaceum according to the botanical keys; others are undoubtedly from hybrid origin and should belong to $S$. bicolor ssp. drummondii. Groups A, D and $\mathrm{E}$ have intermediate characters and seem to be a mix of wild $S$. bicolor ssp. verticilliflorum and introgressed forms (both among wild ecotypes and between wild and cultivated sorghum). Group D constitutes a particular ecotype with high tillering characteristics. The Mantel correlation coefficient of the test between geographic and morphological distance matrices was low but significant $(r=0.09$, $p=0.024)$. Monte Carlo tests on linear discriminant analyses are significant when geographical regions (test value $=0.07, p=0.001$ ), elevation zones (test value $=0.08, p=0.001$ ) and types of habitat (test value $=0.09, p=0.001)$ are used as a priori grouping factors.
The observed geographical structure is mainly due to the geographical distinctiveness of group B $(75 \%$ of individuals originate from the Coastal Province and $20.1 \%$ from the neighboring Eastern Province). The other morphological groups are composed of sorghum of different geographical origins and wild sorghum from the same region are found in several clusters (Table 2). Apart from the geographically well-defined $S$. aethiopicum group B, the observed morphological structures are probably less due to historical differentiation caused by spatial isolation than to genotype by environment interactions, and wild-to-wild or crop-to-wild genetic introgression patterns.

The results of these collections therefore indicate that the current taxonomic status of wild races of Sorghum bicolor is questionable. The classification criteria are mainly quantitative traits that are largely determined by micro-environmental factors. In addition, the different types seem to "grade morphologically and ecologically so completely into one another that they do not deserve formal taxonomic status" (De Wet 1978). It would therefore be better to consider wild specimens of species Sorghum bicolor as ecotypes (De Wet 1978; Clayton and Renvoize 1982) rather than well defined entities with differentiated genetic backgrounds inherited from distinct evolutionary histories.

Strategy for the conservation of sorghum genetic resources in Kenya

Kenya is probably the only country in sub-Saharan Africa that has a fully operational herbarium and National Gene Bank. However, despite efforts to collect and preserve samples of crops and their wild relatives, important gaps still exist. For cultivated sorghum, at least two regions still need sustained collection efforts. The specificity of sorghum cropping systems in the Turkana region (Morgan 1974) is associated with the largest diversity of sorghum landraces cultivated by farmers. The proximity of this region to the presumed primary center of domestication and the adaptation of local germplasm to very dry conditions (rainfall between 200 and $400 \mathrm{~mm} /$ year) makes it a priority target for further collections and implementation of in situ conservation programs. Similarly, the coastal Swahili islands where sorghum cultivation is still important and where sorghum 

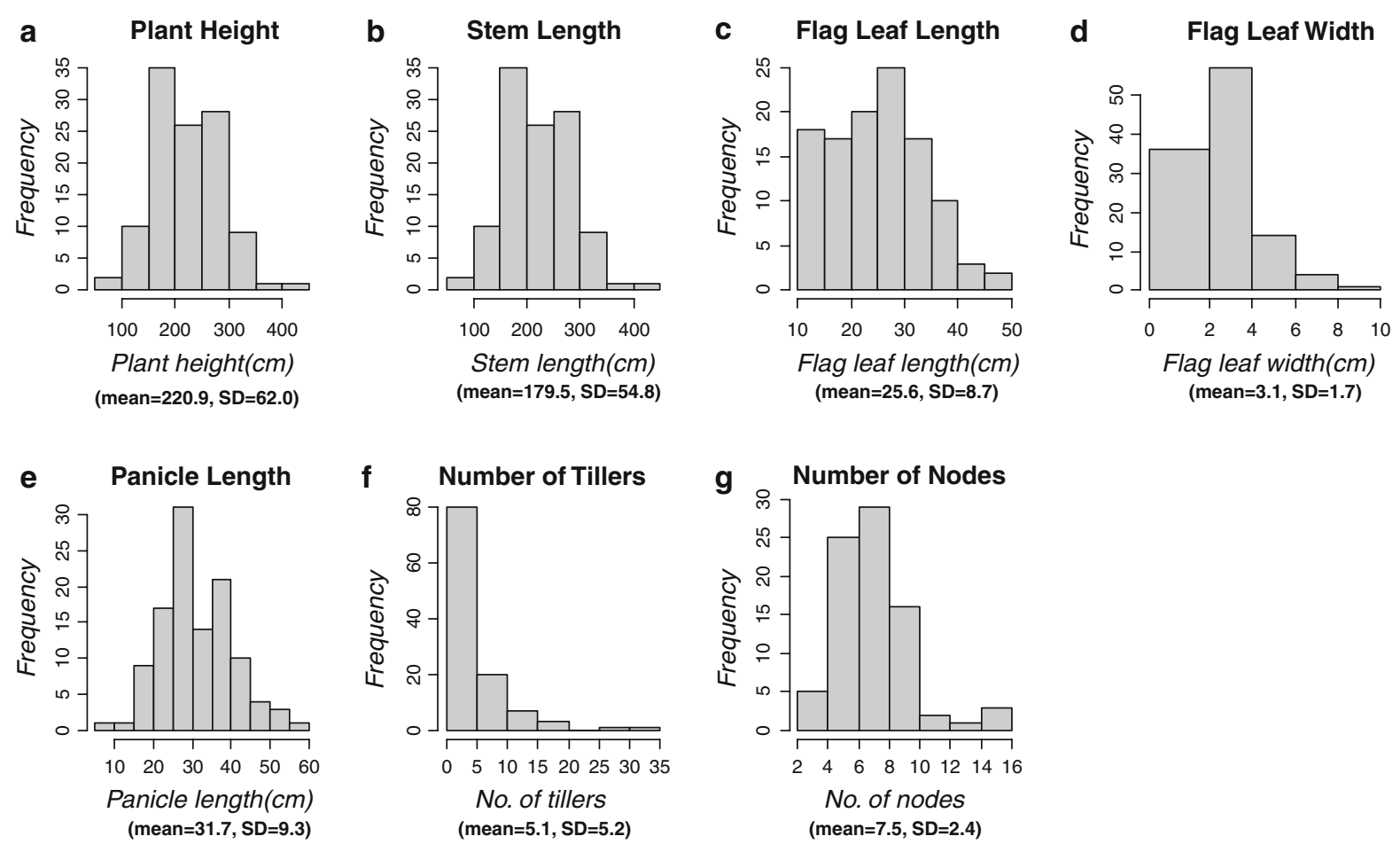

Fig. 4 Variability of wild and weedy sorghum for quantitative traits

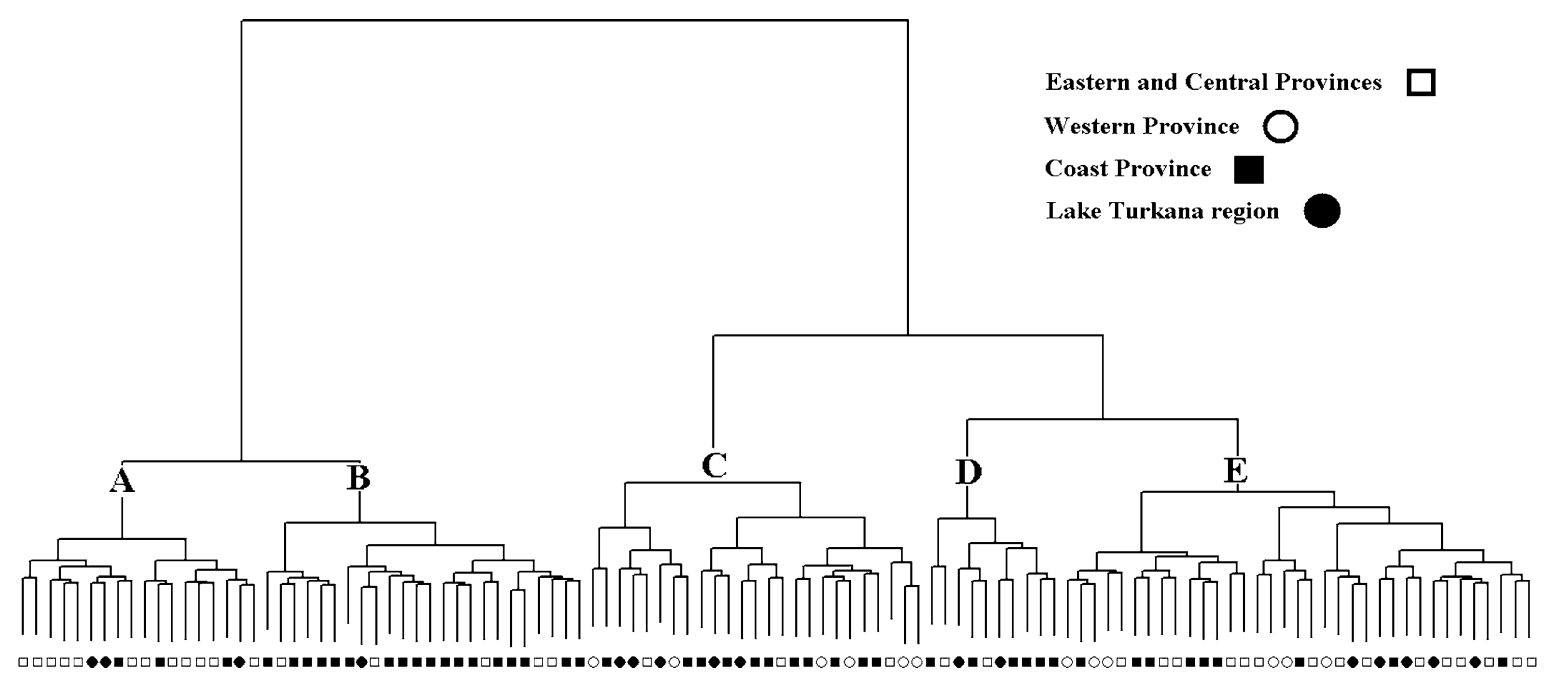

Fig. 5 Dendrogram of the hierarchical cluster analysis performed on 112 wild and weedy sorghum and 7 quantitative traits using Ward's method ( $A, B, C, D$ and $E$ represent the 5 morphological groups described in the "Discussion": paragraph 5)

diversity has benefited from a long history of trade and exchanges, responsible for the creation of original landraces, are to be more thoroughly prospected.

This study has extended the known distribution area of wild sorghum in Kenya. In the Coastal province alone, these collections have provided 33 new accessions (79\%) to the National Gene Bank and new observations in 9 districts. Occurrence of wild sorghum in natural habitats far away from sorghum agriculture is also very important as such populations 
Table 2 Percentage of wild and weedy sorghum from four regions of Kenya (total collection) in each of the five morphological groups identified by the cluster analysis

\begin{tabular}{|c|c|c|c|c|c|}
\hline Morphological groups & $A$ & $B$ & $C$ & $D$ & $E$ \\
\hline East and central provinces & 32.4 & 13.5 & 8.1 & 5.4 & 40.5 \\
\hline Western region & 0.0 & 0.0 & 50.0 & 0.0 & 50.0 \\
\hline Coast province & 6.4 & 38.3 & 23.4 & 12.8 & 19.1 \\
\hline Lake Turkana region & 18.8 & 6.3 & 31.3 & 12.5 & 31.3 \\
\hline
\end{tabular}

could be good candidates for conservation. The fact that wild sorghum are integrated in traditional uses and customs of different tribes, even in pastoralist societies not involved in agriculture, highlights the "African identity" of this plant. The proximity of natural wild populations close to protected areas encourages special efforts to record and map wild sorghum populations in Kenyan national parks, as a further contribution to the national genetic resource conservation policy.

Potential for crop-to-wild gene flow

and environmental risk assessment in Kenya

Wild sorghum are generally considered weeds by African farmers (Doggett 1988). They are found in all regions and grow abundantly on farms, especially in cereal fields. Because they can mimic $\mathrm{C} 4$ cereals such as sorghum, maize and pearl millet during vegetative growth, they often escape selective hand weeding in traditional agricultural systems.

In most sites, mature wild, weedy and cultivated sorghum have been collected at the same time, but a consistent trend was observed towards an earlier maturity of wild plants in all regions. The overlap of flowering periods is enhanced by the tillering ability and seed dormancy of wild sorghum which extend their flowering period at both the individual and population levels. This is confirmed by the study of Tesso et al. (2008), who found sympatric distributions of cultivated and wild sorghum in Ethiopia and Niger with overlapping flowering times, a strong pointer to the possibility of introgression between the two congeners. Similarly, our initial results, that need to be confirmed by molecular marker and agromorphological analyses of the collected material, indicate that the spatial, ecological and phenological barriers to gene flow between cultivated sorghum and their closest wild relatives are not impermeable. Therefore, when considering the potential for sorghum crop-towild gene flow in Kenya, risk assessment surveys of GM sorghum should also focus on the effect of the transgenes on the crop-wild F1 hybrids and further generations of introgression. Transgenes with no effect on fitness would not cause any environmental risk, while resistance genes to herbicides and pests would likely enhance the fitness of crop-wild hybrids and consequently their weediness, especially in the context of intensification of the current agricultural systems.

Transgenic sorghum varieties are not the only agricultural innovations that necessitate the evaluation of potential risks for the environment and cropping systems. The impact of the commercial release, as a fodder crop, of exotic wild sorghum such as Columbus grass (Sorghum $\times$ almum Parodi) which is a perennial rhizomatous hybrid between Sorghum bicolor and Sorghum halepense, in the center of sorghum diversity should also be investigated. Sorghum $\times$ almum is registered as a noxious weed and invasive species in many regions of the world (Randall 2002). Therefore, the observed presence of Columbus grass fields not far from some maize fields that have been dramatically invaded by weedy sorghum along the road between Mwea and Embu Districts, suggests that introgressions with local sorghum varieties have already created aggressive weeds. Similarly, one integrated pest management strategy, the push-pull strategy (Cook et al. 2007) that uses Sudan grass, another exotic weedy sorghum, as a pest trap (mainly for stem borers), close to cultivated maize and sorghum fields, could have serious medium and long term consequences that should be assessed.

Our results show that wild and weedy sorghum are frequently found all over Kenya. The work by Tesso et al. (2008) also made similar observations in major sorghum growing regions in Ethiopia and Niger. Together with locally adapted landraces, wild and weedy relatives of sorghum could contribute significantly to future sorghum breeding programs, especially in the context of expected climate changes. However, they might be threatened by several factors such as the reduction of their habitats and the introgression by cultivated sorghum or exotic wild sorghum grown as fodder crops. Our current knowledge of wild sorghum distribution, diversity and evolution is still limited. As the progenitor of the fifth 
most cultivated cereal in the world, and because it is a prerequisite for in situ conservation (Maxted and Guarino 1997, Heywood et al. 2007) and environmental risk assessment studies, the geographical distribution and ecological dynamics of wild and weedy sorghum deserve more scientific interest. This statement probably holds true for most wild relatives of African indigenous crops.

Acknowledgments The study presented here forms part of the project "Environmental risk assessment of genetically engineered sorghum in Mali and Kenya", funded by the United States Agency for International Development (USAID) Biotechnology and Biodiversity Interface Program. Moses Muraya was awarded a $\mathrm{PhD}$ grant A0523923 from the Deutscher Akademischer Austausch Dienst (DAAD, Germany). We are also grateful to Zackary Muthamia and Geoffrey Mwachalla for the support provided by the National Gene Bank of Kenya and the East African Herbarium, respectively.

\section{References}

Aldrich PR, Doebley J (1992) Restriction fragment variation in the nuclear and chloroplast genomes of cultivated and wild (Sorghum bicolor). Theor Appl Genet 85:293-302

Armstrong TT, Fitzjohn RG, Newstrom LE, Wilton AD, Lee WG (2005) Transgene escape: what potential for cropwild? Mol Ecol 14:2111-2132

Arriola PE, Ellstrand NC (1997) Fitness of interspecific hybrids in the genus sorghum: persistence of crop genes in wild populations. Ecol Appl 7:512-518

Ayoo LMK (2008) Genetic transformation of Kenyan sorghum (Sorghum bicolor (L.) Moench) with anti-fungal genes and response to Collectotrichum sublineolum infection. PhD Dissertation, University of Hamburg, Germany

Casas AM, Kononowicz AK, Haan TG, Zhang LY, Tomes DT, Bressan RA, Hasegawa PM (1997) Transgenic sorghum plants obtained after microprojectile bombardment of immature inflorescences. In Vitro Cell Dev Biol-Plant 33:92-100

Chessel D, Dufour AB, Thioulouse J (2004) The ade4 packageI- one-table methods. R News 4:5-10

Clayton WD, Renvoize SA (1982) Poaceae. Flora of tropical East Africa, part 3. A.A. Balkema, Rotterdam

Conner AJ, Glare TR, Nap JP (2003) The release of genetically modified crops into the environment. Part II-overview of ecological risk assessment. Plant J 33:19-46

Cook SM, Khan ZR, Pickett JA (2007) The use of push-pull strategies in integrated pest management. Annu Rev Entomol 52:375-400

De Wet JMJ (1978) Systematics and evolution of sorghum sect sorghum (Gramineae). Am J Bot 65:477-484

De Wet JMJ, Harlan JR, Price EG (1970) Origin of variability in the spontanea complex of Sorghum bicolor. Am J Bot 57:704-707

Doggett H (1988) Sorghum. Wiley, New York
Doggett H, Majisu BN (1968) Disruptive selection in crop development. Heredity 23:1-26

Ellstrand NC (2003) Dangerous liaisons-when cultivated plants mate with their wild relatives. Johns Hopkins University Press, Baltimore

Ellstrand NC, Prentice HC, Hancock JF (1999) Gene flow and introgression form domesticated plants into their wild relatives. Annu Rev Ecol Syst 30:539-563

Environmental Systems Research Institute (1999) Arcview GIS 3.2. Environmental Systems Research Institute, Inc, USA

Gao Z, Xie X, Ling Y, Muthukrishnan S, Liang GH (2005) Agrobacterium tumefaciens-mediated sorghum transformation using a mannose selection system. Plant Biotechnol J 3:591-599

Girijashankar V, Sharma HC, Sharma KK, Swathisree V, Prasad LS, Bhat BV, Royer M, Secundo BS, Narasu ML, Altosaar I, Seetharama N (2005) Development of transgenic sorghum for insect resistance against the spotted stem borer (Chilo partellus). Plant Cell Report 24:513-522

Gurney AL, Press MC, Scholes JD (2002) Can wild relatives of sorghum provide new sources of resistance or tolerance against striga species? Weed Res 42:317-324

Harlan JR, de Wet JMJ (1971) Toward a rational classification of cultivated plants. Taxon 20:509-517

Harlan JR, de Wet JMJ (1972) A simplified classification of cultivated sorghum. Crop Sci 12:172-176

Heywood V, Casas A, Ford-Lloyd B, Kell S, Maxted N (2007) Conservation and sustainable use of crop wild relatives. Agric Ecosyst Environ 121:245-255

Howe A, Shirley S, Dweikat I, Fromm M, Clemente T (2006) Rapid and reproducible Agrobacterium-mediated transformation of sorghum. Plant Cell Rep 25:751-758

Kamala V, Singh SD, Bramel PJ, Manohar RD (2002) Sources of resistance to downy mildew in wild and weedy sorghum. Crop Sci 42:357-1360

Mantel N (1967) The detection of disease clustering and a generalized regression approach. Cancer Res 27:209-220

Maxted N, Guarino L (1997) Ecogeographic surveys. In: Maxted N, Ford-Lloyd BV, Hawkes JG (eds) Plant genetic conservation: the in situ approach. Chapman \& Hall, London

Morgan WTW (1974) Sorghum gardens in south Turkana: cultivation among a nomadic pastoral people. Geogr J 140:80-93

Morrell PL, Williams-Coplin TD, Lattu AL, Bowers JE, Chandler JM, Patterson AH (2005) Crop-to-weed introgression has impacted allelic composition of Johnsongrass populations with and without recent exposure to cultivated sorghum. Mol Ecol 14:2143-2154

Randall RP (2002) A global compendium of weeds. R.G. and F.J. Richardson Publishers, Merredith

Rao Kameswara N, Reddy LJ, Bramel PJ (2003) Potential of wild species for genetic enhancement of some semi-arid food crops. Genet Resour Crop Evol 50:707-721

Sharma HC, Franzmann BA (2001) Host-plant preference and oviposition response of the sorghum midge, towards wild relatives of sorghum. J Appl Entomol 125:109-114

Snowden JD (1936) The cultivated races of Sorghum. Adlard and Son, London

Snowden JD (1955) The wild fodder Sorghum of the section Eusorghum. J Linn Lond 55:191-260 
R Development Core Team (2005) R: a language and environment for statistical computing. R Foundation for Statistical Computing, Vienna, Austria. ISBN 3-900051-07-0, URL http://www.R-project.org

Tesso T, Kapran I, Grenier C, Snow A, Sweeney P, Pedersen J, Marx D, Bothma G, Ejeta G (2008) The potential for crop-to-wild gene flow in sorghum in Ethiopia and Niger: A geographic survey. Crop Sci 48:1425-1431

Ward J (1963) Hierarchical grouping to optimize an objective function. J Am Stat Assoc 58:236-244

Zhao Z-Y (2008) The Africa biofortified sorghum projectapplying biotechnology to develop nutritionally improved sorghum for Africa. In: Xu Z, Li J, Xue J, Yang W (eds) Biotechnology and sustainable agriculture 2006 and beyond. Proceedings of the 11th IAPTC $\&$ B Congress, Aug 31-18, 2006 Beijing, China. Springer, Netherlands. pp 273-277

Zhao Z-Y, Cai T, Tagliani L, Wang N, Pang H, Rudert M, Schroeder S, Hondred D, Pierce D (2000) Agrobacteriummediated sorghum transformation. Plant Mol Biol 44:789-798

Zhu H, Muthukrishnan S, Krishnaveni S, Wilde G, Jeoung J, Liang G (1998) Biolistic transformation of sorghum using a rice chitinase gene. J Genet Breed 52:243-252 